\title{
Comparison of Balance, Reaction Time, Attention and Bmi Values in Individual and Team Sports
}

\author{
Cenab Turkeri ${ }^{1}$, Bariscan Ozturk ${ }^{2}$, Bilgihan Buyuktas ${ }^{2} \&$ Demet Ozturk $^{2}$ \\ ${ }^{1}$ Physical Education and Sport, Cukurova University, Adana, Turkey \\ ${ }^{2}$ Cukurova University, Institute of Health Sciences, Department of Physical Education and Sports, Adana, \\ Eurkespondence: Cenab Turkeri, Cukurova University, School of Physical Education and Sports, Movement and \\ Traning Science Department, Adana, Turkey. E-mail: cturkeri@cu.edu.tr
}

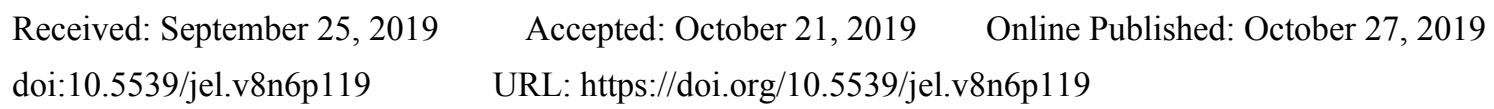

\begin{abstract}
In this study, we aimed to investigate static and dynamic balance, reaction time, attention and BMI values at the athletes being in the individual and team sport. 78 individual athletes (karate 17, judo 15, Gymnastics 14, table tennis 12 , wrestling 20) and 58 team athletes (handball 23, basketball 13, volleyball 10, football 12) with formal licensed and average ages $13.08 \pm 1.36$ years were participated as voluntarily. For demographic characteristics, participants have filled in questionnaires and Bass Stick static balance, $\mathrm{Y}$ dynamic balance, Nelson hand reaction time and D2 attention test were applied. First, we have applied the Kolmogorov-Smirnov test for normality of the data, the normal distribution is observed and then independent $t$ test was used. In order to see the relationship between data, Pearson's correlation test was applied. The average sporting age of participants was $4.32 \pm 1.87$ years, height $1.59 \pm 0.11 \mathrm{~m}$, body weight $50.18 \pm 12.74 \mathrm{~kg}$ and per week training time $10.33 \pm 4.41$ hours. In addition, their BMI values were $19.49 \pm 3.10 \mathrm{~kg} / \mathrm{m}^{2}$ which is in the normal range, i.e., no difference between individual and team athletes was observed. It has been observed that for individual athletes, total number of items is $525.42 \pm 108.29$, total number of errors is $454.04 \pm 105.86$, concentration performance is $182.14 \pm 62.53$, reaction rime is $0.29 \pm 0.06 \mathrm{sec}$, static balance is $7.10 \pm 4.49 \mathrm{sec}$, dynamic balance is $208.37 \pm 32.20 \mathrm{~cm}$. On the other hand, for team athletes, these values were $500.59 \pm 79.70,382.31 \pm 93.60,168.35 \pm 56.51,0.26 \pm 0.05 \mathrm{sec}$, $5.68 \pm 2.67 \mathrm{sec}$ and $187.15 \pm 29.99 \mathrm{~cm}$, respectively.
\end{abstract}

We have found that while age increased the static and dynamic balance increased, but training time increased solely the dynamic balance increased. In addition, when taking into account the static and dynamic balance, it has been observed that the individual athletes were better than the team athletes but for the reaction time was contrary, i.e., team athletes were better than the individual ones.

Keywords: individual and team sports, D2 attention test, Nelson hand reaction test, Y dynamic balance test, Bass stick static balance test

\section{Introduction}

Sports can be done individually or in teams. It is specialized activities like athletic, technical, psychological, physical and physiological, based on competitive, exhibiting visible results, bringing together communities for general purpose.

There are also many different meanings. Sports is a scientific phenomenon, cooperates with many disciplines that enables the individual to compete his/her physical, cognitive and affective characteristics in the definite rules including performance-based competitive. Sports are divided into subsections in many respects. One of these distinctions is individual and team sports. Individual sports are sports such as athletics and swimming, exhibiting performance which cannot be prevented by the other competitor, and sports such as wrestling, karate and table tennis where the individual tries to beat his opponent according to the rules determined by using the techniques of the sport that is being performed together with the perceptual, cognitive and motor characteristics of the individual. Team sports; these are the sports in which two different teams or groups try to beat the opponent team with the winning conditions (goals, points, etc.) created according to certain rules by using perceptual, cognitive, motor characteristics and techniques of the sports branch being performed. We think that there is a need for publications in which individual attention, balance and reaction properties are investigated 
together in the sports of individual and team sports. When these characteristics, everyone has a particular importance, is evaluated together, will be beneficial for individual sports or team sports, especially for training planning.

Because team sports branches have sports competitions involving more than one person, athletes show their performance in certain positions with their task distribution. Although everyone has a common goal in team sports, each team member has a separate task. According to this task, it is inevitable to have different characteristics in the person. Therefore, while some characteristics of team athletes are different from other members of the team (which can shoot better, etc.), some features are expected to be close together (all together fast offense etc.). Individually the fact that a member of the team is very good is not a sufficient factor for success.

In the individual sports branches, the athlete may succeed in the competition with the characteristics he has born and developed further and with the will to exhibit these characteristics. What is expected from the athlete here is that he exhibits his innate abilities and technical characteristics of the sport in the best way. The athlete competes in with himself. To exhibit all the features needed by the sport branches sufficiently and without mistake, and it is the individual athlete's responsibility and the success or failure is directly his own. Many characteristics of individual and team athletes were compared (Ozer \& Kılınç, 2011; Salar, Hekim, \& Tokgöz, 2012). The comparison of basic motor skills is generally the first studies that come to mind. However, other cognitive and perceptual skills need to be compared. In some studies; it has been stated that there is no doubt that performance in sport is related to cognitive and perceptual skills as well as motor and physical ability, and the importance of the subject has been emphasized (Barlow, Woodman, Gorgulu, \& Voyzey, 2016; Schwab \& Memmert, 2012). Measuring one's the state of attention is one of them. Attention, dynamic and static balance, reaction speed and the relationship between all sport skills such as individual and team sports to know the differences will also provide us with important information.

Attention includes the process of filtering our perceptions, balancing our various perceptions and adding emotional importance to our perceptions. Attention is the key element of the ability to control thought processes and the ability to concentrate on a task for effective performance in sport (Nideffer, 1993). Attention has a very important role in the performance display in sport. During all sporting activities (regardless of competition or training), attention needs to be maintained to a sufficient level.

Balance is a necessary condition to be able to movement, and is a trait that can be achieved through highly complex processes intertwined (Sirmen, 2008; Tetik, 2013). Balance has been described as "an important factor in the combination of sporting performance and physical fitness in everyday life" (Aksu, 1994). The balance is examined under two headings as static and dynamic. Static balance is defined as the ability to maintain the support base with minimal move, while dynamic balance is the ability to perform a movement while maintaining a position (Cerrah, 2016). Another important issue for balance is the adequacy of proprioceptive senses. Balance is an immutable part of many daily life skills and covers many neuromuscular stages. Balance is achieved by interpreting the stimulation obtained from vestibular, proprioceptive, and visual receivers in the central nervous system, by the harmony of muscles and their sudden responses, and by the arrangement of the body's center of gravity (Brosseau et al., 2005; Hinman, Bennell, Metcalf, \& Crossley, 2002). Our body and the position of the extremities are important in maintaining the static-dynamic balance. The position of our body and extremities are important in maintaining static-dynamic balance. Especially during the movement of the body possible wobbles or loss of balance can be prevented with the participation of extremities in the movement.

Reaction time is the time that passes until the first response to these stimuli after a stimulus reaches the body (Karagöz, 2008). It is the time between the first reaction that occurs after the appearance of a sensory, visual or tactile stimulus. Reaction time can be improved by repetitive well-constructed studies. Reaction time is a factor that can affect the result in many aspects of sport.

BMI is the ratio of body weight to height. Its purpose is to inform the person with the most appropriate body weight that should be. It is found by dividing the body weight into the square of the height $\left(\mathrm{kg} / \mathrm{m}^{2}\right)$. Obesity classification is evaluated according to BMI classification table. Body mass index (BMI), adopted by the World Health Organization in obesity studies, obtained from anthropometric measurements, body weight and height measurements, is a valid standard height-weight index that is easily accessible, applicable to all persons regardless of gender (Ergün, \& Erten, 2004; Turkeri, 2014). After the BMI is calculated, it is generally classified as weak, normal weight, overweight and obese.

In our study, no comparison literature was found in which the parameters we measured were taken and evaluated in the same way at once. However, there are studies with some parameters of team athletes or individual athletes 
and have been used in comparisons.

\section{Method}

\subsection{Participants}

The universe of research is composed of athletes who participate in individual and team sports branches licensed in Adana province. The sample included total 136 athletes 78 individual athletes (karate 17, judo 15, gymnastics 14 , table tennis, 12 , wrestling 20) and 58 team athletes (handball 23 , basketball 13 , volleyball 10 , football 12) with formal licensed and average ages $13.08 \pm 1.36$ years were participated as voluntarily. In addition, the participants were height: $1.59 \pm 10 \mathrm{~m}$ and body weight: $50.17 \pm 12.74 \mathrm{~kg}$. Volunteer forms were signed before starting the study. Cukurova University received approval from the Ethics Committee for non-interventional clinical research with decision number 04.09.19/91-68.

In Table 1, The average age of the participants was $13.08 \pm 1.36$ years, sports age was $4.32 \pm 1.87$ years, body weight was $50.18 \pm 12.74 \mathrm{~kg}$, their height was $1.59 \pm 0.11 \mathrm{~m}$ and they practiced $10.33 \pm 4.41$ hours per week. When the BMI values were taken into consideration, the participants were in the $19.49 \pm 3.10 \mathrm{~kg} / \mathrm{m}^{2}$ normal range.

Table 1. Demographic characteristics of individual and team athletes

\begin{tabular}{llll}
\hline & $\begin{array}{l}\text { Individual athletes }(\mathrm{n}=78) \\
\overline{\mathrm{x}} \pm \mathrm{sd}\end{array}$ & $\begin{array}{l}\text { Team athletes }(\mathrm{n}=58) \\
\overline{\mathrm{x}} \pm \mathrm{sd}\end{array}$ & $\begin{array}{l}\text { All athletes }(\mathrm{n}=136) \\
\overline{\mathrm{x}} \pm \mathrm{sd}\end{array}$ \\
\hline Age (year) & $12.95 \pm 1.57$ & $13.26 \pm 1.00$ & $13.08 \pm 1.36$ \\
Height $(\mathrm{m})$ & $1.56 \pm 0.11$ & $1.64 \pm 0.08$ & $1.59 \pm 0.11$ \\
Body Weight $(\mathrm{kg})$ & $47.71 \pm 13.14$ & $53.50 \pm 11.47$ & $50.18 \pm 12.74$ \\
BMI & $19.41 \pm 3.38$ & $19.60 \pm 2.70$ & $19.49 \pm 3.10$ \\
Sport Age (year) & $4.02 \pm 1.78$ & $4.72 \pm 1.93$ & $4.32 \pm 1.87$ \\
Weekly Training Time & $11.06 \pm 4.92$ & $9.36 \pm 3.41$ & $10.33 \pm 4.41$ \\
\hline
\end{tabular}

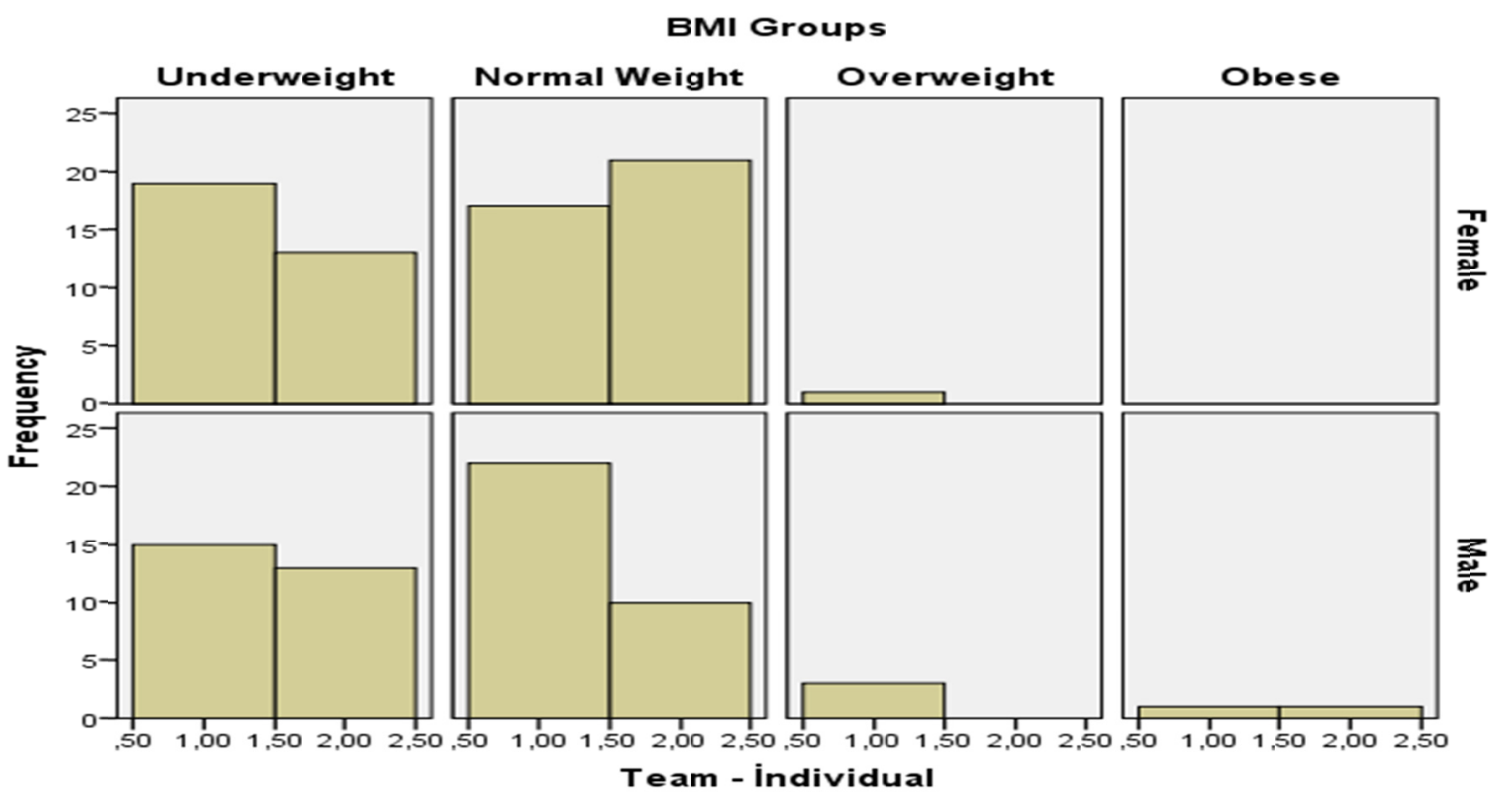

Figure 1. Graph of BMI grouping and individual and team by gender of athletes 


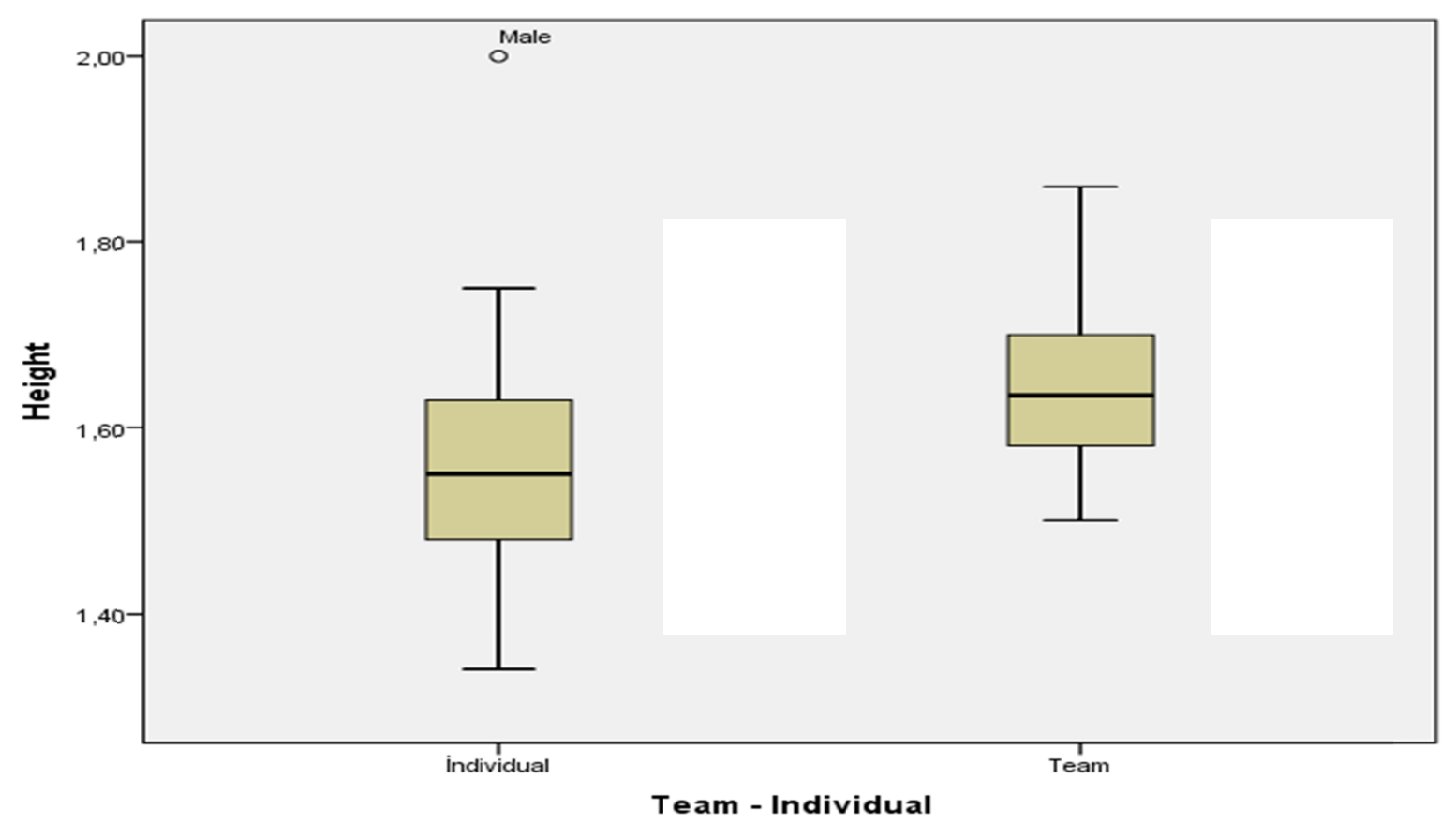

Figure 2. Graph of height and individual-team

\subsection{Demographic Characteristics}

A questionnaire form was used to determine demographic characteristics (gender, age, height, weight, sports branch, sports year, how many hours of training per week).

\subsection{Data Collection Tools}

Bass Stick Static Balance Test, Nelson Hand Reaction Test, Y Dynamic Balance Test, D2 Attention Test, BMI (Body Mass Index) and Personal Information Form were used in the study in order to collect data.

\subsubsection{Bass Stick Static Balance Test}

Static balance measurements were performed by Bass Stick Lengthwise Test method $(2.5 * 2.5 * 30.5 \mathrm{~cm})$ using wooden stick. The subjects were instructed to stand hands free on the bare foot for a long time on the dominant feet and to touch the fixed leg with the leg of the unstable leg and the subjects were allowed to perform two trials. The stopwatch is activated as soon as the balance position is taken, and the stopwatch is stopped when the subject loses his or her balance or touches the ground with his or her bent foot (Turkeri, 2014).

\subsubsection{Nelson Hand Reaction Test}

While the subject is sitting on the chair, the forearm and hand rests on the table in a comfortable way. The person is asked to prepare $8-10 \mathrm{~cm}$ thumb and index finger tips on the outside of the table so that the upper parts of the thumb and index finger are parallel to each other. The Test manager held the ruler so that it was between the subject's head and forefingers. The subject was asked to look directly at the midpoint of the ruler and was told to grab the ruler with the thumb and forefingers as soon as the ruler was released. When the ruler was left, the line of the ruler on the upper edge of the thumb, where the subject captured the ruler, was read and recorded. Measurements were repeated 20 times with the best 5 and worst 5 measurement degrees removed, with the average of the remaining 10 degrees recorded in $\mathrm{cm}$ (Tamer, 2000).

$$
\text { Reaction Time }=\sqrt{ } 2 * \text { ruler struck distance }(\mathrm{cm}) / \text { gravity connected speed }(\mathrm{sec})
$$

\subsubsection{Y Dynamic Balance Test}

Dynamic balance measurements were made using $\mathrm{Y}$ dynamic balance test. The validity and reliability of the test were determined by Plisky et al., The ICC range was $0.85-0.01$ and the interrater range $0.99-1.00$. The subjects are in a stable balance with their feet naked in their sportswear and their feet in the center point of the $\mathrm{Y}$ balance test assembly, with the dominant foot in the center point. The other toe then pushes the blocks with the toe (rotating the foot to the stationary stop point each time without touching the floor), maintaining its fixed position 
in the anterior $\left(0^{\circ}\right)$, posteromedial $\left(45^{\circ}\right)$ and posterolateral $\left(45^{\circ}\right)$ directions. The test is repeated 3 times in all three directions (anterior, posteromedial, posterolateral) and averaged and recorded in centimeter.

\subsubsection{D2 Attention Test}

D2 attention test was used to determine the attention levels of the participants. This test was developed by Brickenkamp (1962). The D2 test consists of 14 lines and 47 marked letters. To evaluate mental concentration and selective attention (Yayci, 2013). Validity and reliability of D2 test on athletes and sedentary has been studied in Turkey (Yayc1, 2013; Bektaş, 2013). As a result of the study on athletes; It was emphasized that Cronbach's Alpha value was determined as Total Item (0.95), total item-error (0.96) and concentration score (0.96). According to the study results of Yayci (2013), the D2 attention test on sedentary was reported to have Cronbach's Alpha value as total substance (0.831), total item-error (0.831), concentration score (0.877). It is reported that the D2 test can be applied to people aged 9-60 years, individually or in groups (Çağlar \& Koruç, 2006; Yayc1, 2013; Bektas, 2013).

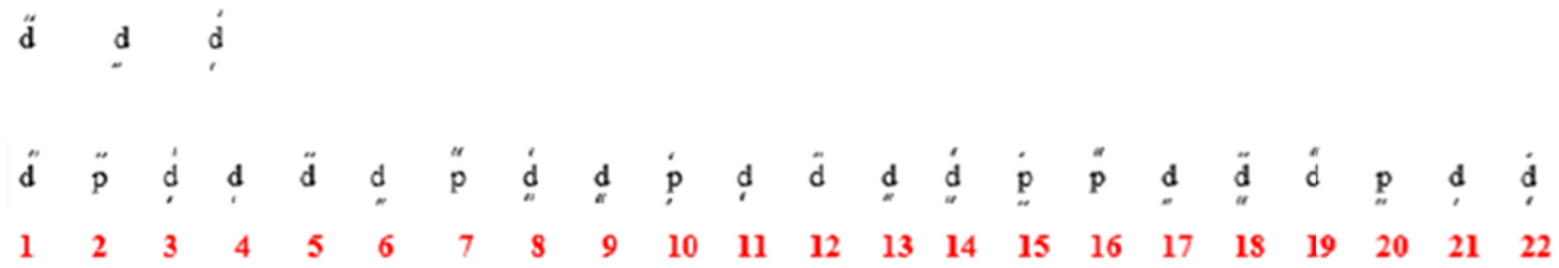

Figure 3. D2 test example

D2 Attention Test Application Protocol: The test, which consists of 14 lines, has the letters "p" and "d" on each line. However, there are 16 different signed letters with a different number of comma marks above or below them. The participant is asked to mark (/) on the correct letter during the application by considering the following sample letters. Other letters and signs should be ignored. For each row, the participant is allowed 20 seconds. It is expected to make both fastly and accurately marking within 20 seconds. In our study, the test was conducted in small groups of 6 persons, at the same time of day and in a quiet environment.

\subsubsection{BMI (Body Mass Index)}

Body Mass Index (BMI) is calculated by dividing body weight by the square of the height $(\mathrm{kg} / \mathrm{m} 2)$. body mass index assessment was performed according to the abbreviated evaluation table given in Table 2 published by the Turkish Ministry of Health.

Table 2. BMI evaluation table

\begin{tabular}{lll}
\hline$<18.5$ & $\mathrm{~kg} / \mathrm{m}^{2}$ below & Underweight \\
$18.5-24.9$ & $\mathrm{~kg} / \mathrm{m}^{2}$ between & Normal Weight \\
$25-29.9$ & $\mathrm{~kg} / \mathrm{m}^{2}$ between & Overweight \\
$30-39.9$ & $\mathrm{~kg} / \mathrm{m}^{2}$ between & Obese \\
\hline
\end{tabular}

\subsection{Statistical Analysis}

The statistical analysis SPSS 22.0 software package was used. For descriptive statistics, mean \pm standard deviation values were calculated. Kolmogorov-Smirnow test was performed for homogeneity of variances. Parametric tests were used because of the normal distribution of variances. For the differences between individual and team athletes as well as comparisons between male and female athletes, independent sample $t$ test was used. Pearson correlation test was used to determine the relationships between some parameters.

\section{Results}

The results of the statistical analysis of the obtained data are shown in Tables 3, 4, 5, 6, 7, 8 and 9. In Table 3 shows the distribution of sports branches according to the genders of individual and team athletes. It was observed that individual athletes (78 people $57.4 \%$ ) and team athletes (58 people $42.6 \%$ ). When gender was examined, it was found that female (71 people $52.2 \%$ ) and male (65 people $47.8 \%$ ). 
Table 3. Distribution of Sport Branches by Gender of Individual and Team Athletes

\begin{tabular}{|c|c|c|c|c|c|c|c|c|c|c|}
\hline \multirow{2}{*}{$\begin{array}{l}\mathrm{n}=136 \\
\text { Branches }\end{array}$} & \multicolumn{5}{|c|}{$\begin{array}{l}\text { Individual sports }(\mathrm{n}=78) \\
57.4 \%\end{array}$} & \multicolumn{5}{|c|}{$\begin{array}{l}\text { Team sports }(\mathrm{n}=58) \\
42.6 \%\end{array}$} \\
\hline & $\begin{array}{l}\text { Judo } \\
11.0 \% \\
\end{array}$ & $\begin{array}{l}\text { Gymnastic } \\
10.3 \% \\
\end{array}$ & $\begin{array}{l}\text { Karate } \\
12.5 \% \\
\end{array}$ & $\begin{array}{l}\text { Wrestling } \\
14.7 \%\end{array}$ & $\begin{array}{l}\text { Table Tennis } \\
8.8 \% \\
\end{array}$ & $\begin{array}{l}\text { Basketball } \\
9.6 \%\end{array}$ & $\begin{array}{l}\text { Football } \\
8.8 \%\end{array}$ & $\begin{array}{l}\text { Volleyball } \\
7.4 \%\end{array}$ & $\begin{array}{l}\text { Handball } \\
16.9 \%\end{array}$ & Total \\
\hline $\begin{array}{l}\text { Female } \\
52.2 \%\end{array}$ & 7 & 14 & 13 & 0 & 3 & 1 & 0 & 10 & 23 & 71 \\
\hline $\begin{array}{l}\text { Male } \\
47.8 \%\end{array}$ & 8 & 0 & 4 & 20 & 9 & 12 & 12 & 0 & 0 & 65 \\
\hline Total & 15 & 14 & 17 & 20 & 12 & 13 & 12 & 10 & 23 & 136 \\
\hline
\end{tabular}

In Table 4, the BMI values of individual and team athletes showed that individual athletes (43.6\%) were weak and $(50.0 \%)$ were normal weight values, while team athletes $(44.8 \%)$ were weak and $(53.4 \%)$ were normal weight values. Overall, overweight $(2.9 \%)$ and obese $(1.5 \%)$ were found to be very low in all participants.

Table 4. BMI values classification of individual and team athletes

\begin{tabular}{lllllll}
\hline & \multicolumn{2}{l}{ Individual Athletes } & \multicolumn{2}{c}{ Team Athletes } & \multicolumn{2}{c}{ All Athletes } \\
& $\mathrm{n}$ & $\%$ & $\mathrm{n}$ & $\%$ & $\mathrm{n}$ & $\%$ \\
\hline Underweight & 34 & 43.6 & 26 & 44.8 & 60 & 44.1 \\
Normal Weight & 39 & 50.0 & 31 & 53.4 & 70 & 51.5 \\
Overweight & 4 & 5.1 & - & - & 4 & 2.9 \\
Obese & 1 & 1.3 & 1 & 1.7 & 2 & 1.5 \\
Total & 78 & 100.0 & 58 & 100.0 & 136 & 100.0 \\
\hline
\end{tabular}

Table 5 shows the comparison of static balance, dynamic balance and reaction time values of individual and team athletes. Static balance values $(p=0.02)$ and dynamic balance values $(p=0.00)$ of individual athletes were higher than team athletes. Reaction time values $(\mathrm{p}=0.00)$ of team athletes were found to be better than individual athletes.

Table 5. Comparison of static balance, dynamic balance and reaction time values of individual and team athletes

\begin{tabular}{lllllll}
\hline Parameters & Group & $\mathrm{n}$ & $\overline{\mathrm{x}}$ & $\mathrm{sd}$ & $\mathrm{t}$ & $\mathrm{p}$ \\
\hline Static Balance $(\mathrm{sec})$ & Individual & 72 & $\mathbf{7 . 1 0}$ & 4.49 & 2.25 & $\mathbf{0 . 0 2 *}$ \\
& Team & 58 & 5.68 & 2.67 & & \\
Dynamic Balance $(\mathrm{cm})$ & Individual & 78 & $\mathbf{2 0 8 . 3 7}$ & 32.20 & 3.91 & $\mathbf{0 . 0 0 *}$ \\
& Team & 58 & 187.15 & 29.99 & & \\
Reaction Time & Individual & 72 & 0.29 & 0.06 & 3.19 & $\mathbf{0 . 0 0 *}$ \\
& Team & 57 & $\mathbf{0 . 2 6}$ & 0.05 & & \\
\hline
\end{tabular}

Note. ${ }^{*} \mathrm{p} \leq 0.05$.

Table 6 shows the comparison of static balance, dynamic balance and reaction time values according to the gender of the participants. While there was no difference between male and female in static balance values, significant difference was found between dynamic balance values $(p=0.00)$ and reaction time values $(p=0.00)$ in favor of male athletes.

Table 6. Comparison of participants Bass stick static balance, Y dynamic balance, reaction and BMI values by gender

\begin{tabular}{lllllll}
\hline Parameters & Group & $\mathrm{n}$ & $\overline{\mathrm{x}}$ & $\mathrm{sd}$ & $\mathrm{t}$ & $\mathrm{p}$ \\
\hline Static Balance(sec) & Female & 67 & 6.71 & 4.19 & 0.74 & 0.46 \\
& Male & 63 & 6.21 & 3.44 & & \\
Dynamic Balance(cm) & Female & 71 & 190.40 & 24.01 & -3.44 & $\mathbf{0 . 0 0}^{*}$ \\
& Male & 65 & $\mathbf{2 0 9 . 0 6}$ & 38.31 & & \\
Reaction Time (sec) & Female & 66 & 0.29 & 0.06 & 3.50 & $\mathbf{0 . 0 0}^{*}$ \\
& Male & 63 & $\mathbf{0 . 2 6}$ & 0.05 & & \\
\hline
\end{tabular}

Note. ${ }^{*} \mathrm{p} \leq 0.05$. 
Table 7 shows the comparison of D2 attention test measurement parameters according to individual and team athletes. The total item-error values of individual athletes were significantly higher $(p=0.00)$ than team athletes. The lower total item error means that athletes have a better attention. Total item values $(p=0.13)$ and concentration score values $(\mathrm{p}=0.19)$ were similar in individual and team athletes.

Table 7. Comparison of total item, total item-error and concentration score values of D2 attention test of individual and team athletes

\begin{tabular}{lllllll}
\hline Parameters & Group & $\mathrm{n}$ & $\overline{\mathrm{x}}$ & $\mathrm{sd}$ & $\mathrm{t}$ & $\mathrm{p}$ \\
\hline Total İtem & Individual & 78 & 525.42 & 108.29 & 1.54 & 0.13 \\
& Team & 58 & 500.59 & 79.70 & & \\
Total İtem Error & Individual & 78 & 454.04 & 105.86 & 4.10 & $\mathbf{0 . 0 0 *}$ \\
& Team & 58 & $\mathbf{3 8 2 . 3 1}$ & 93.60 & & \\
\multirow{2}{*}{ Concentration Score } & Individual & 78 & 182.14 & 62.53 & 1.32 & 0.19 \\
& Team & 58 & 168.35 & 56.51 & & \\
\hline
\end{tabular}

Note. ${ }^{*} \mathrm{p} \leq 0.05$.

Table 8 shows the comparison of the total item, total item-error and concentration score values of D2 attention test according to the gender of the participants. There was no gender difference between D2 caution test values.

Table 8. Individual and team athletes D2 attention test, total item, total item-error and the concentration score value comparison by gender

\begin{tabular}{lllllll}
\hline Parameters & Group & $\mathrm{n}$ & $\overline{\mathrm{x}}$ & $\mathrm{sd}$ & $\mathrm{t}$ & $\mathrm{p}$ \\
\hline Total İtem & Female & 71 & 502.17 & 102.48 & -1.59 & 0.11 \\
& Male & 65 & 528.66 & 9070 & & \\
Total İtem-Error & Female & 71 & 407.85 & 110.35 & -1.80 & 0.07 \\
& Male & 65 & 440.49 & 100.37 & & \\
Concentration Score & Female & 71 & 178.01 & 65.05 & 0.35 & 0.72 \\
& Male & 65 & 174.34 & 54.88 & & \\
\hline
\end{tabular}

Table 9 shows the relationship between age, sport age, weekly training time, static balance, dynamic balance and reaction times of all participants. There was a significant but low negative relationship between age and reaction time $(\mathrm{p}=0.05, \mathrm{r}=-0.17)$, and a significant but low correlation between dynamic balance and static balance $(\mathrm{p}=$ $0.00, \mathrm{r}=0.26)$.

Table 9. The relationship between age, sport age and weekly training hours of all athletes and static balance, dynamic balance and reaction time values

\begin{tabular}{|c|c|c|c|c|c|c|}
\hline \multirow[t]{2}{*}{$\mathrm{n}=136$} & \multicolumn{2}{|c|}{ Static Balance } & \multicolumn{2}{|c|}{ Dynamic Balance } & \multicolumn{2}{|c|}{ Reaction Time } \\
\hline & $\mathrm{r}$ & $\mathrm{p}$ & $\mathrm{r}$ & $\mathrm{p}$ & $\mathrm{r}$ & $\mathrm{p}$ \\
\hline Age & $0.172 *$ & $0.05^{*}$ & 0.214 * & $0.01 *$ & -0.168 & 0.06 \\
\hline Sport Age & -0.004 & 0.96 & 0.097 & 0.26 & -0.073 & 0.41 \\
\hline Weekly Training Time & 0.069 & 0.37 & 0.471 * & $0.00 *$ & -0.144 & 0.16 \\
\hline
\end{tabular}

Note. ${ }^{*} \mathrm{p} \leq 0.05$.

\section{Discussion and Conclusion}

It has been demonstrated in many studies that individual and team athletes have different motoric characteristics (Ozer \& Kilinc, 2011; Salar, Hekim, \& Tokgöz, 2012). However, other cognitive and perceptual skills need to be examined together with motoric skills. There are studies indicating that sport performance is related to cognitive and perceptual skills as well as motor and physical ability (Barlow et al., 2016; Schwab \& Memmert, 2012). The aim of this study is to investigate static balance, dynamic balance, reaction time, attention and BMI values of athletes competing in individual and team sports branches. We have investigated totally 136 persons in which 71 females (52.2\%), 65 males (47.8\%) and 78 athletes (57.4\%) individual athletes (15 judo, 14 gymnastics, 20 wrestling, 12 table tennis, 17 karate) and 58 ones (42.6\%) team sport (10 volleyball, 12 football, 13 basketball, 23 handball), between licensed athletes, actively participating in competition. The mean age and sport age of 
athletes were found to be $13.08 \pm 1.36$ and $4.32 \pm 1.87$ years, respectively. The mean height and body weight of athletes were $1.59 \pm 0.11$, and $50.18 \pm 12.74 \mathrm{~kg}$, respectively. In 2018, Ince and Yildirim has obtained the mean age and sport age of the handball and hockey athletes as $13.53 \pm 0.59$ and $2.85 \pm 0.75$ years, respectively, in agreement with the values observed in our study. In this study, the mean BMI values of the athletes were found as $19.49 \pm 3.10$ of $\mathrm{kg} / \mathrm{m}^{2}$. In a study related to balance and flexibility, Hazar and Tasmektepligil (2008) has found the BMI value as $18.17 \pm 2.91 \mathrm{~kg} / \mathrm{m}^{2}$ for the children at the age of $11.12 \pm 0.96$ years. In another study performed on the $13.8 \pm 1.7$ years old, Arabaci (2008) has found the BMI values as $19.6 \pm 2.3 \mathrm{~kg} / \mathrm{m}^{2}$ which is in agreement with the values obtained in the frame work of this study.

When taking into account the relationship between age, sport age, weekly training time and static balance, dynamic balance, reaction time, it was found significant values between age and static balance as $r=0.172$ and $p$ $=0.05$. On the other hand, it was found low but significant relationship between age and dynamic balance as $\mathrm{r}=$ 0.214 and $\mathrm{p}=0.01$. Additionally, moderate significant relationship was observed as $r=0.471$ and $p=0.00$, between weekly training time and dynamic balance. According to our findings, it can be argued that static and dynamic balance is better with increasing age, and dynamic balance is better with increasing weekly training hours.

In our study, Bass Stick static balance values were found as $7.10 \pm 4.48 \mathrm{sec}$ in individual athletes and $5.67 \pm 2.67$ $\mathrm{sec}$ in team athletes. Reed et al. (2004) has found the static balance value as $28.12 \pm 17.49$ second for the experiment performed on the students of secondary school which is above our values. Turkeri (2014) has found the value of Bass Stick static balance as $18.93 \pm 12.30 \mathrm{sec}$ in his study on university students. It can be argued that the high mean values of student age $(22.7 \pm 2.10$ years $)$ may reveal the difference in measurements. When the Y dynamic balance total scores were examined, it was found that individual athletes had $208.37 \pm 32.20 \mathrm{~cm}$ and $187.14 \pm 29.98 \mathrm{~cm}$ for team athletes.

Vural (2016) in a study conducted on male basketball players aged $17.6 \pm 0.5$ years, Y total score of dynamic balance has found as $252.42 \pm 6.89 \mathrm{~cm}$. Shaffer et al. (2013) found that the Y dynamic balance total score was $239.3 \pm 21.5 \mathrm{~cm}$ for athletes whose age was $25.2 \pm 3.8$ years. The reason for the low Y dynamic balance values obtained in our study may be due to the smaller age group.

Erkmen et al. (2007) compared the balance performances of athletes in different branches and found that the dynamic balance performance of gymnastics athletes was better than football players, and their static and dynamic balance performances were better than basketball athletes and its value was significant $(p \leq 0.05)$. In the present study, when it is compared the values of $p=0.02$ and 0.00 , for static and dynamic balances, respectively, significant difference was found in favor of individual athletes. The reason for the difference may be due to the athletes in the individual sports branches that we take measurements in our study, move by short steps without running in the competition and technical trainings; use of their bodies more steadily on the ground without much jumping and technical applications in very narrow area (distance is very short for the technical applications of karate, wrestling, table tennis, judo sports) and usage of different training floor (polyurethane and rubber cushion) comparison to team sports.

In the present study, in D2 attention test comparison between individual and team athletes, no significant difference was found in total item and concentration scores. In terms of total item error values, $p=0.00$ significant difference was found in favor of team sports. This result shows that team athletes made fewer errors in the D2 attention test. In team sports, the reason of less mistakes in their attention made by athletes may be due to the continuously following of their team mates and competing athletes during offense and defense situations. Thus, we can say that the target of keeping team performance constantly high by increasing attention gain may have improved attention.

In our study, reaction time measurements were found as $0.29 \pm 0.06 \mathrm{sec}$ in individual athletes and $0.26 \pm 0.05$ $\mathrm{sec}$ in team athletes. Menevse (2011) found that the reaction time in handball athletes whose ages were $22.28 \pm$ 2.05 years was $0.25 \pm 0.01$. This result is close to our results obtained for team sports, the small difference may be due to the age difference of the measurements group. The findings were generally consistent with the reaction time findings with the results obtained in the frame work of this measurement. In our study, significant $p=0.00$ difference was found in favor of team athletes in terms of reaction time between individual and team athletes, and a significant $\mathrm{p}=0.00$ difference was found in favor of male athletes between male and female.

Koc et al. (2006) found in their study performed on football and tennis athletes that football players have better reaction time than tennis ones $(\mathrm{p}=0.01)$. In the same study, it was found that male had better right-hand reaction time than female athletes $(\mathrm{p}=0.05)$, and team athletes had better reaction times than individual athletes, i.e., football players are better than wrestlers, handball players are better than athletics athletes $(p \leq 0.05)$. Arabaci 
(2008) found a significant difference in male and female athletes under the age of 15 (13.8 \pm 1.7 years) in favor of male $(p=0.00)$. These findings coincide with the results obtained in our study. Accordingly, it can be said that male athletes have better reaction time than female athletes and team athletes have better reaction time than individual athletes.

As a result; it was found that dynamic balance increased with increasing training time, static and dynamic balance increased with increasing age, static and dynamic balance status of individual athletes were better than team athletes, and finally, reaction time and attention of team athletes were better than individual athletes.

\section{References}

Aksu, S. (1994). Denge Ĕgitiminin Etkilerinin Postüral Stres Testi İle Değerlendirilmesi. Hacettepe Üniversitesi Sağlık Bilimleri Enstitüsü Bilim Uzmanlığı Tezi, Ankara. Thesis no: 37887

Arabac1, R. (2008). The Comparison of Physical Fitness of Female and Male Badminton Players Under 15 Years. E-Journal of New World Sciences Academy, 3(1-2), 5-6. ISSN:1306-3111. Article Number: B0009

Barlow, M., Woodman, T., Gorgulu, R., \& Voyzey, R. (2016). Ironic Effects of Performance Are Worse for Neurotics. Psychology of Sport and Exercise, 24, 27-37. https://doi.org/10.1016/j.psychsport.2015.12.005

Bektas, F. (2013). Evaluating Elite Mountaineers' Levels of Attention at Different Altitudes with The D2 Attention Test. Middle-East Journal of Scientific Research, 16(5), 571-576.

Brosseau, L. et al. (2005). Ottawa Panel Evidence-Based Clinical Practice Guidelines for Therapeutic Exercises and Manual Therapy in The Management of Osteoarthritis. Physical Therapy, 85(9), 907-971. https://doi.org/10.1093/ptj/85.9.907

Cağlar, E., \& Koruç, Z. (2006). D2 Dikkat Testinin Sporcularda Güvenirliği ve Geçerliği. J. of Sport Sciences, 17(2), 58-80. Retrieved from https://dergipark.org.tr/tr/pub/sbd/issue/ 16401/171458

Cerrah, A., Bayram, İ., Yıldızer, G., Uğurlu, O., Şimşek, D., \& Ertan, H. (2016). Fonksiyonel Denge Antrenmanının Adölesan Futbolcuların Statik ve Dinamik Denge Performansları Üzerine Etkileri. International Journal of Sport, Exercise \& Training Sciences, 2(2), 73-81. https://doi.org/10.18826/ijsets.38897

Ergün, A., \& Erten, F. (2004). Öğrencilerde Vücut Kitle İndeksi ve Bel Çevresi Değerlerinin İncelenmesi Ankara Üniversitesi Tip Fakültesi Mecmuasl, 57(2), 57-61. https://doi.org/10.1501/Tipfak_0000000102

Erkmen, N., Suveren, S., Göktepe, A. S., \& Yazıcıoğlu, K. (2007). Farklı Branşlardaki Sporcuların Denge Performanslarının Karşılaştırılması. Spormetre Beden Eğitimi ve Spor Bilimleri Dergisi, 3, 115-122. https://doi.org/10.1501/Sporm_0000000080

Hazar, F., \& Taşmektepligil, Y. (2008). Puberte Öncesi Dönemde Denge Ve Esnekliğin Çeviklik Üzerine Etkilerinin İncelenmesi. Spormetre Beden Eğitimi Ve Spor Bilimleri Dergisi, Vl(1), 9-12. https://doi.org/10.1501/Sporm_0000000130

Hinman, R., Bennell, K., Metcalf, B., \& Crossley, K. (2002). Balance Impairments in Individuals with Symptomatic Knee Osteoarthritis: A Comparison with Matched Controls Using Clinical Tests. Rheumatology, 41(12), 1388-1394. https://doi.org/10.1093/rheumatology/41.12.1388

Ince, G., \& Yildirim, A. (2018). Top İle Oynanan Spor Branşlarında Aparat Kullanımının, Sporcu Dikkat Performansı Üzerine Etkisi: Pilot Çalışma. Uluslararası Antrenman Bilimi, Spor, Egzersiz Dergisi, 123. https://doi.org/10.18826/useeabd.445340

Karagöz, Ş., (2008). 8-10 Yaş Arası Çocuklarda 12 Haftalık Tenis Antrenmanlarının Görsel ve İşitsel Reaksiyon Zamanına Etkisinin İncelenmesi. Afyon Kocatepe Üniversitesi Sağlık Bilimleri Enstitüsü. Yüksek Lisans Tezi. Retrieved from http:/hdl.handle.net/11630/3022

Koç, H., Kaya, M., Sarıtaş, N., \& Çoksevim, B. (2006). Futbolcularda ve Tenisçilerde Bazı Fiziksel ve Fizyolojik Parametrelerin Karşılaştırılması. Sağlık Bilimleri Dergisi. Journal of Health Sciences, 15(3), 161-167. Retrieved from https://dergipark.org.tr/tr/pub/eujhs/issue/4 4518/ 552044

Menevşe, A. (2011). Elit Düzeydeki Hentbolcularda Müsabaka Öncesi ve Sonrası Reaksiyon Zamanları İle Müsabaka Performansları Arasındaki İlişsinin İncelenmesi. Yüksek Lisans Tezi İnönü Üniversitesi Beden Eğitimi ve Spor Anabilim Dalı, Malatya. Thesis No: 293453

Nideffer, R. M. (1993). Concentration and Attention Control Training. In J. M. Williams (Ed.), Applied Sport Psychology Personal Growth to Peak Performance (pp. 243-261). California: Mayfield Publishing Company. 
https://jjsimpson.com/tpsi/tais/libcontent/rn/ACT_2006.pdf

Ozer, O., \& Kılınç, F. (2011). Elit Bireysel ve Takım Sporcuların Kuvvet, Sürat ve Esneklik Performanslarının Karşılaştırılması. Uluslararası Insan Bilimleri Dergisi, 9(1), 360-371. ISSN:1303-5134. Retrieved from https://www.j-humansciences.com/ojs/index.php/ IJHS/ article/view/ 2171

Plisky, P. J., Gorman, P. P., Butler, R. J., Kiesel, K. B., Underwood, F. B., \& Elkins, B. (2009). The Reliability of an Instrumented Device for Measuring Components of the Star Excursion Balance Test. N Am J Sports Phys Ther., 4(2), 92-99. PMCID: PMC2953327. PMID: 21509114.

Reed, J. A., Metzker, A., \& Phillips, D. A. (2004). Relationships Between Physical Activity and Motor Skills in Middle School Children. Perceptual and Motor Skills, 99(2), 483-494. https://doi.org/10.2466/pms.99.2.483-494

Salar, B., Hekim, M., \& Tokgöz, M. (2012). 15-18 Yaş Grubu Takım ve Bireysel Spor Yapan Bireylerin Duygusal Durumlarının Karşılaştırılması. Mehmet Akif Ersoy Üniversitesi Sosyal Bilimler Enstitüsü Dergisi, 9(6), 123-135. Retrieved from https://dergipark.org.tr/tr/pub/makusobed/ issue/19438/ 206734

Schwab, S., \& Memmert, D. (2012). The Impact of a Sports Vision Training Program in Youth Field Hockey Players. Journal of Sports Science and Medicine, 11(4), 624-631. https://www.jssm.org/hf.php?id=jssm-11-624.xml\#

Shaffer, S. W., Teyhen, D. S., Lorenson, C. L., Warren, R. L., Koreerat, C. M., Straseske, C. A., \& Childs, J. D. (2013). Y-Balance Test: A Reliability Study Involving Multiple Raters. Military Medicine, 178(11), 1264 1270. https://doi.org/10.7205/MILMED-D-13-00222

Sirmen, B., Atilgan, O., Uzun, S., Ramazanoglu, N., Atil, Z., \& Danismen, E., (2008). The Compartson of Statıc Balance and Postural Sway of Waterpolo Players, Karate Athletes and Sedentary People. In 50th ICHPER-SD Anniversary World Congress Japan.

Tamer, K., Cicioğlu, I., \& Günay, M. (2000). Spor Fizyolojisi ve Performans Ölçümü (pp. 52-57). Ankara: Bağırgan Yayınevi. ISBN: 9789756009055

Tetik, S., Koç, M. C., Atar, Ö., \& Koç, H. (2013). Basketbolcularda Statik Denge Performansı İle Oyun Değer Skalası Arasındaki İlişkinin İncelenmesi. Türkiye Kickboks Federasyonu Spor Bilimleri Dergisi, 6(1), 9-18. ISSN: 1309-1336. https://hdl.handle.net/20.500.12432/2081

Turkeri, C. (2014). Oniki Haftalık Salsa Dans Çalışmalarının Vki ve Statik Dengeye Etkisi. Çukurova Üniversitesi Ĕgitim Fakültesi Dergisi, 01-22. https://doi.org/10.14812/cufej.2015.001

Vural, M. U. (2016). Life Kinetik Antrenmanının Genç Erkek Basketbolcularda Denge, Reaksiyon Süresi ve Dikkat Üzerine Etkisi. Yüksek Lisans Tezi, 39. Gazi Üniversitesi Sağlık Bilimleri Enstitüsü. Science Code: 1301

Yayc1, L. (2013). D2 Dikkat Testinin Geçerlik ve Güvenirlik Çalışması. Kalem Eğitim ve İnsan Bilimleri Dergisi, 3(1), 43-80. https://doi.org/10.23863/kalem.2017.19

\section{Note}

It will be presented as an oral presentation at the 17th International Congress of Sport Sciences which will be held between 13-16 November 2019 in Antalya.

\section{Copyrights}

Copyright for this article is retained by the author, with first publication rights granted to the journal.

This is an open-access article distributed under the terms and conditions of the Creative Commons Attribution license (http://creativecommons.org/licenses/by/4.0/). 